\title{
高圧ボイラー用水の条件*
}

\section{Water Condition for High Pressure Boiler}

\author{
D. E. Voyles** and E. C. Fiss***
}

Corrosion, Vol. 13, No. 9, 589t 590t (1957) Sept.

\section{緒容}

この論交の目的は, 運転圧力が 94.5〜129.5 atmであ り, その使用水の固形物含量が $10 \mathrm{ppm}$ 以下である蒸気 ボイラーに用いる氷の条件についての Duke Power Company の経験と実地作業について概論するにある。

ここで述べる装置は約 $330^{\circ} \mathrm{C}$ 飽和蒸気をボイラーで 発生させ, $538^{\circ} \mathrm{C}$ に過熱する $129.5 \mathrm{~atm}$ ののと同じで ある。この過熱蒸気はタービンの 8 段の高圧部で膨脹し て28.7atmとなり, この圧力でボイラーの再熱部に行っ て再び538 $\mathrm{C}$ に加熱される。再熱された蒸気はそれから タービンの残りの段階で膨脹し, 水銀で約 $37.5 \mathrm{~mm}$ の絶 対圧力で主復水器に排気される。排気蒸気は大略 $32^{\circ} \mathrm{C}$ で凝結し, 二つの管状熱交換器と一つの開放脱気加熱器 を通って $4.9 \mathrm{~atm}$ に圧縮され，ボイラー給水ポンプの吸 込口では温度が $154^{\circ} \mathrm{C}$ になる。ホイラー給水ポンプは二 つの補助的管状熱交換器にボイラー圧力で給水し, 給水 はボイラーの節炭部に入るところで約 $232^{\circ} \mathrm{C}$ の温度にな る。

\section{構 成 材 料}

上述したような水蒸気サィクル装置の構成材料につい て概説すると次のようになる。

ボイラー管と過熱器の低温部とはA-192の低炭素鐝よ りなる。過熱器の高温部と再熱器の管は $\mathrm{Cr}-\mathrm{Mo}$ 鋼 (A 213-T11执よびA213-T22）よりなる。タービンの高温 段階の部品は $12 \% \mathrm{Cr}$ 鋼, そして残りの段階は主として 低合金鋼または炭素鋼よりなる。復水器と低温給水加熱 器の管はアドミラルティ黄銅, そしてその外板は単味の 炭素鋼よりなる。復水器ポンプのインペラーは青銅で, ボイラー給水ポンプのインペラーは，2％Cr 鋼である。 高温給水加熱器の管は 80-20キュプロニッケルで, 給水 管系はA-106の炭素鋼でめる。

ボイラーの缶水ブロー, 脱気加熱器の排気, 然料滓の 吸出しなどが, 蒸気発生率の約 $0.5 \%$ に相当する水損失 の原因である。この損失は蒸発のまたは鉱物質除去の装 置によって補われるが, それらの装置は溶解全固形物が $1 \mathrm{ppm}$ 以下で, 溶解シリカが $0.1 \mathrm{ppm}$ 以下の水を供給

\footnotetext{
* 訳者 伊藤伍郎 科学研究所

** Duke Power Company.

*** Carollinas-Virginia Nuclear Power Associates.
}

できることが保証されたものである。蒸発器の場合に は，溶存酸素を $0.001 \mathrm{ppm}$ 以下に，また全 $\mathrm{CO}_{2}$ 量を約 $0.5 \mathrm{ppm}$ に減らすことのできる燐酸処理と開放給水加熱 器とが前置してある。

復水器の脱気部は凝結水中の溶存酸素量の代表的值を 約 $0.01 \mathrm{ppm}$ に保つのに有効な作用をし，また脱気給水 加熱器は溶存酸素を $0.007 \mathrm{ppm}$ 以下に減らすことが侵 証されている。

\section{運 転 条 件}

これらの装置の水の条件に関した代表的運転条件の概 略は次の通りである。

蒸発または鉱物質を除去した補給水は約 $2.72 \mathrm{t} / \mathrm{hr}$ たは約 $0.5 \%$ てる。給水系の脱気加熱器は給水の機裁 的脱気を最良に保つために水を $0.27 \sim 0.36 \mathrm{t} / \mathrm{hr}$ の割合 で取り出す。冷却水が系内にもれないようにするために 復水器は水密に保たれる。ヒドラジンを脱気給水に絶え ず補給して，それがいつもボイラー水中に残っているの が測定できるような十分な割合で加える。ポイラーの䓄 水ブローは約 $0.23 \mathrm{t} / \mathrm{hr}$ で絶えず行なう。

このような運転作業を行なうと水の条件は第 1 表に示 す通りの結果となる。ここで示された鉄と銅の值はそれ ぞれの試験法の比色指示薬として batho-phenanthrolineと neo-cuproine を用いて測定したものであり, 銑 量の決定にあたっては鉄をすべて溶解させてしまうたる に試料は酸性にした。この試験によれば, 真の濃度はこ こに示した範囲内にありまたおそらくここに示した值よ りは低いであろうことがすぐに決定できるだけの精度を もっていることが感ぜられた。

ヒドラジンの濃度は dimethylaminobenzaldehyde 比色法によって求め, なたアンモニア濃度はネスラー反 応により求めた（アンモニアはヒドラジンの反応生成物 として生ずる)。ここに示した值の数字なたは範囲は蒸 気発生能力が $280 〜 453 \mathrm{t} / \mathrm{hr}$ にわたる13個のボイラーで みられた通常の運転条件である。これらのボイラーは18 月〜9年にわたる範囲の期間使用されたものであり, そ れらのうらの五つは制御循環型のものである。

\section{ボイラー缶水ブロー}

ボイラー亦中の溶解シリカには制限があり,この限界 がボイラーの年水ブローの割合を決定する支配因子であ 
第 1 表

\begin{tabular}{|c|c|c|c|c|c|}
\hline & 凝結 水 & 蒸留補給水 & 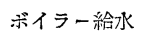 & ボイラー水 & 過熱水蒸気 \\
\hline $\mathrm{pH}$ & $8.5 \sim 9.0$ & $6.0 \sim 7.0$ & $8.5 \sim 9.0$ & $8.5 \sim 9.0$ & $8.5 \sim 9.0$ \\
\hline 伝導度 (脱ガスせず)：m mhos & $1.0 \sim 2.0$ & $1.0 \sim 2.0$ & $1.0 \sim 2.0$ & $2 \sim 10$ & $1.0 \sim 2.0$ \\
\hline ヒドラジン： ppm $\mathrm{N}_{2} \mathrm{H}_{4}$ & - & - & - & $0.01 \sim 0.05$ & - \\
\hline アンモニア：ppm $\mathrm{NH}_{3}$ & $0.1 \sim 0.2$ & $<0.1$ & - & - & - \\
\hline 銅：：ppm Cu & $<0.01$ & $<0.01$ & $<0.01$ & $<0.01$ & $<0.01$ \\
\hline : $p p m ~ F e$ & $<0.01$ & $<0.01$ & $<0.01$ & $<0.01$ & $<0.01$ \\
\hline
\end{tabular}

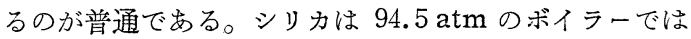
$3 \mathrm{ppm}$ 以下に, また $129.5 \mathrm{~atm}$ の装置では $1 \mathrm{ppm}$ 以下 に調制する。ブローの代表的な割合として $0.23 \mathrm{t} / \mathrm{hr}$ を 用いればこのような濃度に保つことは容易である。ボイ ラーを使用しはじめた短い期間以外には混濁は決して認 められなかった。

ボイラーのブローの必要な割合がたとえ低くとも，絶 えず行なうことが望ましいと著者は考えるのであるが， これはこのような操作によって水の状態を安定に保ら， かつボイラー氷の試料採取点がブロ一線にあるときに採 取がたしかにうまくできるからである。しかし水の保存 をきびしく要求されるような運転条件の時には, 毎日の ボイラー氷試料採取のためフラッシュするに必要な量以 外は数週間にわたってブローせずに運転したボイラーも いくつかある。このような期間にボイラー我中の固形物 の增加することは認められなかった。

ボイラーの内面は毎年検査されるが，その表面は脆い 粉状の被覆に覆われているのが普通で，その分析成分は $\mathrm{Fe}_{3} \mathrm{O}_{4}$ が約70\%, $\mathrm{Cu}$ が25\%であり, 少量の $\mathrm{Ni}, \mathrm{Zn}$ お よびその他の金属を含有していた。ボイラーの缶胴にも これらの物質はいくらかめった。

酸素腐食による管の破壊がここで取上げているボイラ 一のうちの二つに括こったが，それらはいずれも運転休 止㐫るいは軽負荷などの運転期間のときに酸素が給水中 に入ったことによることがわかった。酸素除去のための
薬品の残りはこの期間になくなってしまったのである。 そこでボイラー給水中に酸素の入るのをなるべく少なく するような運転条件を採用し，また酸素除去剤がボイラ 一亦中にいつでも残っているように極力注意することに よって管の故障をなくすことができた。

運転をはじめる前にボイラーの各部はミルスケールを 除くために化学洗浄をした。管の外観検査で酸化物付着 を除く必要があると認められた時にはそれを除くために 化学的洗浄を行なうのが著者の考えである。今日では腐 食破壊を起した二つのボイラーだけに化学洗浄が行な われた。一つは 8 年, 他は 7 年間の運転後であった。を のほか数個のボイラーが近い将来に洗浄が行なわれると 期待されており，これらのボイラーは特とらく約 5 年の 期間で洗浄を必要とするようになるらしい。

これらのボイラーから蒸気を受け取るタービンで付着 物の堆積のために段落圧力の增加が認められたり, 給水 加熱器が洗浄を必要とするようになったりしたことはな かった。タービンは通常 3 年間の運転後に検查され, 翼 の飽和点付近で少量の物質の付着がみられた。この物質 は主としてシリカで, 磁性酸化鉄を若干含んでいる。凝 結水の $\mathrm{pH}$ は一貫して約 8.5 で, タービン部品は部分的 に $\mathrm{pH}$ が低い状態になった様子はない。

ここで述べた㞄転経験によって, 高圧蒸気ボイラール 固形物含量の比較的少ない水を用いれば長期にわたって なんらの困難なしに運転できることを知った。

\title{
亜硝酸塩による腐食防止の実際例 ${ }^{*}$ Nitrite Inhibition of Corrosion : Some Practical Cases
}

\author{
T. P. Hoar**
}

Corrosion, Vol. 14, No. 2, 103t 104t (1958) Feb.

緒言

1943 年 Wachter \& Smith ${ }^{1)}$ が, ガソリン・パイプ

* 訳者 村山健司 日本石油株式会社 中央技衍研究所

** Cambridge Univ. 治金学講師, 腐食関係の技術士
ラインの腐食を亜硝酸ナトリウム溶液で防止して以来, 腐食防止に亜硝酸塩を利用することが非常に発展した。 覀硝酸塩の作用機構に関する研究も行なわれているが, その理論はまだ完全とはいえない。本稿は英国における 